Historic, Archive Document

Do not assume content reflects current scientific knowledge, policies, or practices. 

If you want to buy your trees for the least money why not send your order direct to us and pay only your own bill.

\section{APPLE TREES}

2 years old, 4 to $5 \mathrm{ft}$.

Each

2 years old, 3 to $4 \mathrm{ft}$. $25 \mathrm{c}$

1 year old, 4 to $5 \mathrm{ft}$. $15 \mathrm{c}$

1 year old, 3 to $4 \mathrm{ft}$.

1 year old, 2 to $3 \mathrm{ft}$.

Early May

Yellow Transparent

Early Harvest

Red June

Sweet Bough

Summer Queen

Liveland Raspberry

Maiden Blush
Varieties in Order of Ripening

\section{Jonathan}

Rambo

Grimes Golden

Red Delicious

King David

Yellow Delicious

York Imperial

Rome Beauty
Champion

Stayman's Winesap

Black Ben Davis

Winesap

Mammoth Blacktwig

Ark Black

Ingram

\section{PEACH TREES}

5 to $7 \mathrm{ft}$. high

Each $30 \mathrm{c}$

4 to $5 \mathrm{ft}$. high $22 \mathrm{c}$

3 to $4 \mathrm{ft}$. high $15 \mathrm{c}$

2 to $3 \mathrm{ft}$. high

$10 \mathrm{c}$

16 to 24 inches high-Elbertas and Hale only $5 c$

Varieties of Peaches in Order of Ripening

$\begin{array}{lll}\text { Mayflower } & \text { Slappey } & \text { Crawford's Early } \\ \text { Early Wheeler } & \text { Carmen } & \text { Elberta } \\ \text { Arp Beauty } & \text { Champion } & \text { Hale } \\ \text { Redbird Cling } & \text { Bell of Georgia } & \text { Elberta Cling } \\ \text { Alton } & \text { Chinese Cling } & \text { Salway } \\ \text { Mamie Ross } & & \text { Heath Cling } \\ \text { Early Elberta } & & \text { Detober Krummel }\end{array}$

\section{PEAR TREES}

Duchess

2 years old, 4 to 6 feet high Seckell

Garber

$50 \mathrm{c}$ each

Kiefer

\section{PLUM TREES}

4 to $5 \mathrm{ft}$. high

May Beauty

Red June
2 to $3 \mathrm{ft}$. high

Wild Goose

America

Sapa
3 to $4 \mathrm{ft}$. high

$30 \mathrm{c}$

Burbank

Hanski

\section{CHERRY TREES}

4 to $5 \mathrm{ft}$. high $65 \mathrm{c}$

2 to $3 \mathrm{ft}$. high

3 to $4 \mathrm{ft}$. high $50 \mathrm{c}$

$40 \mathrm{c}$

$40 c$

Early Richmond, Montmorency, Governor Wood, English Merrello.

Compass Cherry (a cross between cherry and plum)

\begin{tabular}{l}
\hline \multicolumn{3}{c}{ MISCELLANEOUS FRUITS } \\
Quinces, 3 to $4 \mathrm{ft}$. high \\
Russian Mulberries, 4 to $5 \mathrm{ft} .55 \mathrm{c}$ Apricots, 3 to $4 \mathrm{ft}$ Nectarines, 3 to $4 \mathrm{ft}$. $50 \mathrm{c}$ \\
Crab Apples (Hyslop or Transcendant), 3 to $4 \mathrm{ft}$ \\
4 to $5 \mathrm{ft}$.
\end{tabular}

If you will give us an opportunity to assist you in the selection of your fruit trees, we can help your orchard more than you think, especially in apples, as some varieties do best in the western part and some in the eastern part of this state. 


\section{GRAPES}

Concord-1 year, No. 1 10 c each; doz., $\$ 1.00 ; 100, \$ 7.00 ; 1,000, \$ 50.00$

Concord-2 years $15 \mathrm{c}$ each; 100 for $\$ 10.00$

Moore's Early, Niagara, Worden, Catawba $20 \mathrm{c}$ each; $100, \$ 15.00$

\section{BIACKBERRIES}

Dallas, Robinson, Mercereau

Early Harvest or McDonald

$\$ 3.00$ per 100

McDonald will not bear alone-should have Early Harvest or Dallas planted with it.

\section{RASPBERRIES}

Miller Red, Cuthbert, Kansas, Cumberland, St. Regis

$\$ 3.00$ per 100

\section{MISCELLANEOUS BERRIES}

Lucretia Dewberries $\$ 2.50$ per 100 Houghton Gooseberries_._...15c each Thornless Dewberries $\$ 5.00$ per 100 Downing Gooseberries_______._._. $25 \mathrm{c}$ each

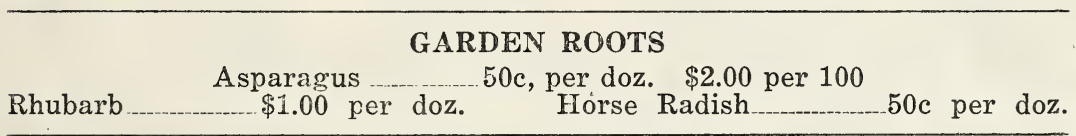

\section{FLOWERING SHRUBS}

Hydrangia, each

$50 \mathrm{c}$

Snowball, each $50 \mathrm{c}$

Althea, White or Prirple, each _._._50c

Chinese Honeysuckle, each $30 \mathrm{c}$

Wegelia, each $50 \mathrm{c}$

California Privett, 2 to $3 \mathrm{ft}$, per 100

Lilac, White or Purple, each $50 \mathrm{c}$

Calacanthus, each $50 \mathrm{c}$

Spirea Billardi, each Spirea Van Houttii, each $50 e$

Purple Wisteria, each $50 \mathrm{c}$

THE FOLLOWING ITEMS FOR SPRING PLANTING:

Canna Bulbs, Red or Yellow

$75 \mathrm{c}$ per doz.

\section{STRAWBERRY PLANTS}

They are scarce, due to the drouth this year, and hard to get; must be higher than in years.

$100 \quad 75$ c. $500 \quad \$ 3.00$. $1,000 \quad \$ 5.00$. All post paid. Excelsior, Premier, Senator Dunlap, Klondyke, Aroma.

The New Mastodon Everbearing Strawberry, the greatest of them all: $\$ 2.00$ per 100

$\$ 15.00$ per 1,000 Postpaid.

\section{SWEET POTATO PLANTS}

We will have Sweet Potato plants ready on and after April 15th, and at the following prices:

100 Delivered by parcel post__._.50 $\$ 1,000$ delivered by parcel post $\$ 3.00$ 500 Delivered by parcel post $1.75 \quad 10,000$ express collect____- 25.00

Varieties of Sweet Potatoes

Nancy Hall

Yellow Yam

Southern Queen

Triumph

Porto Rico

Red Bermuda

Don't give your order for trees to an agent or dealer and expect to get as good trees as cheap as they are listed here. It can't be done. This is the day of mail orders, and we are asking for that class of business and promise a square deal.

\section{OZARK NURSERY CO.}


No. 616

\section{CERTIFICATE OF NURSERY INSPECTION}

Office of State Board of Agriculture

Oklahoma City, Oklahoma

September 3, 1929.

This Is to Certify, That in accordance with Senate Bill No. 342 of the Session Laws of 1914-15, the Nursery S'tock, consisting of 10 acres, now growing for sale by Ben Davis, Owner, Ozark Nursery Company, Tahlequah, Oklahoma, has been inspected by a duly authorized inspector and found to be apparently free from dangerously injurious insects and plant diseases. Invalid after October 1, 1930.

Countersigned:

R. E. MONTGOMERY, State Inspector.

H. B. CORDELL, President State Board of Agriculture.

The following table shows the amount that will be required to pay the postage on your order if it amounts to less than $\$ 10.00$. If more than $\$ 10.00$ we pay the postage or express.

Apples, Peaches, Plums or other stock, 2 years, 4 to $5 \mathrm{ft}$. high, cut back so as to send by parcel post.

$\begin{array}{rrcc} & \text { Up to } 150 \text { Miles } & 150 \text { to } 300 \text { Miles } & 300 \text { to } 600 \text { Miles } \\ 1 \text { to } 5 \text { trees } & 18 \mathrm{c} & 29 \mathrm{c} \\ 6 \text { to } 10 \text { trees } & 28 \mathrm{c} & 49 \mathrm{c} \\ 11 \text { to } 17 \text { trees } & -17 \mathrm{c} & 46 \mathrm{c} & 85 \mathrm{c}\end{array}$

Apples, Peaches, Pears, Plums, Cherries and all other trees in the 3 to 4

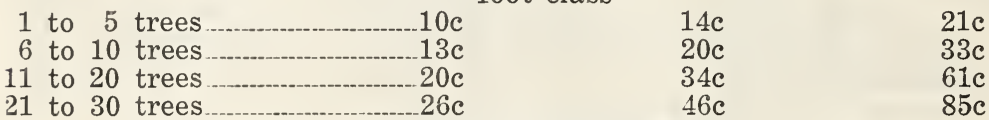

21 to 30 trees $\quad 26 c$ Shrubs, Grape Vines, Gooseberries, Canna, Rhubarb, Etc.

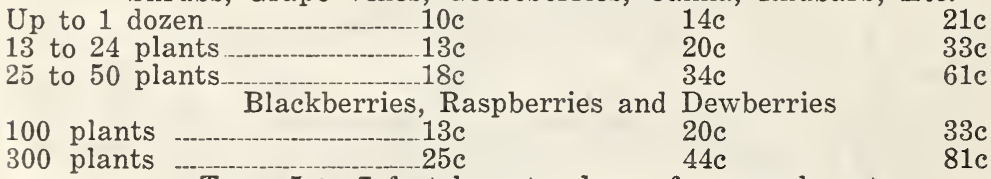

Trees 5 to 7 feet long too large for parcel post.

\section{CLUB ORDERS}

If you will get your neighbor to order with you, it will save you money-both of you. If you do not want $\$ 10.00$ worth of trees, but the two of you do want $\$ 10.00$, then we will pack the orders separate, tag each, and ship together, and pay the express, and if by taking in several of your neighbors you can get $\$ 50.00$ or $\$ 100.00$ worth, we will pack separate, tag each, ship all together and allow you the discounts.

\section{OZARK NURSERY CO.}

Tahlequah, Oklahoma 